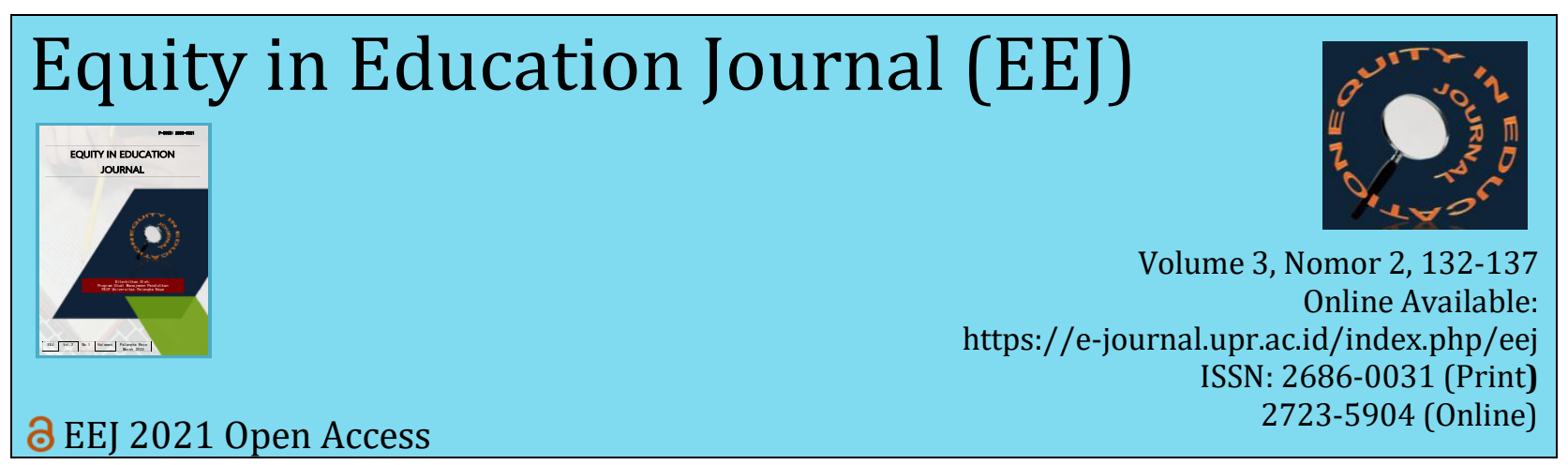

\title{
MANAJEMEN HUMAS DALAM PROGRAM PRAKTIK KERJA INDUSTRI JURUSAN PERHOTELAN SMKN 3 PALANGKA RAYA
}

\author{
Wahyu Wisnu Setiawan* Slamet Winaryo, Teti Berliani \\ FKIP, Universitas Palangka Raya, Palangka Raya
}

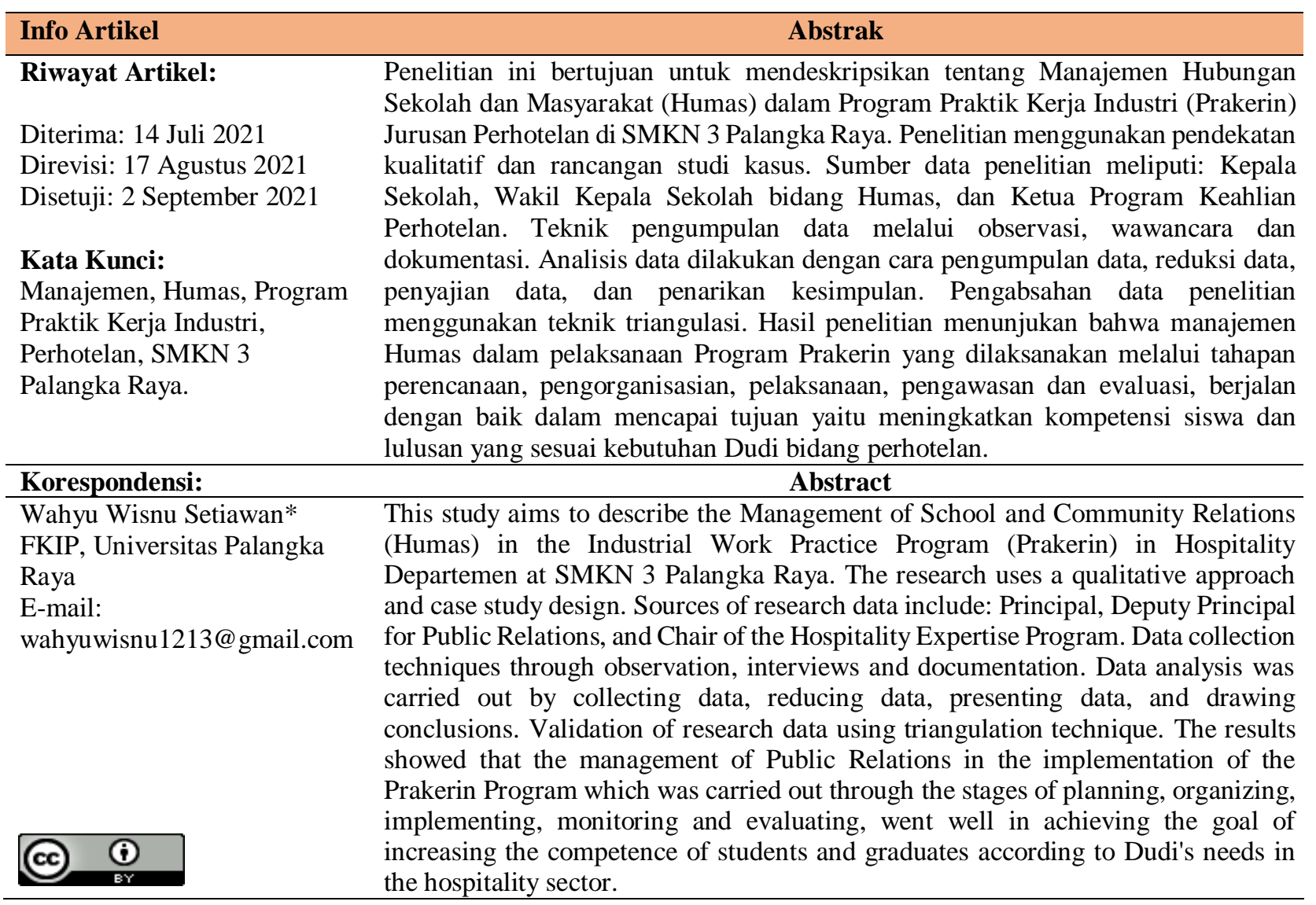

\section{PENDAHULUAN}

Pendidikan saat ini berupaya menyiapkan sumber daya manusia yang berkualitas, terampil dan sesuai dengan kebutuhan berbagai sektor, khususnya dunia usaha dan dunia industri. Upaya untuk menciptakan sumber daya manusia yang berkualitas tersebut, tertuang dalam ketentuan umum Bab I Pasal 1 Undang-Undang Nomor 20 Tahun 2003 tentang Sistem Pendidikan Nasional, menyatakan bahwa: "Pendidikan adalah usaha sadar dan terencana untuk mewujudkan suasana belajar dan proses pembelajaran agar peserta didik secara aktif mengembangkan potensi dirinya untuk memiliki kekuatan spiritual keagamaan, pengendalian diri, kepribadian, kecerdasan, akhlak mulia, serta keterampilan yang diperlukan dirinya dan masyarakat, bangsa dan negara". 
Satuan pendidikan yang mewadahi pengembangan peserta didik yang berkualitas, terampil dan kompeten dalam bidang kompetensi keahliannya secara khusus adalah melalui pendidikan di Sekolah Menengah Kejuruan (SMK). SMK sebagaimana dinyatakan dalam Peraturan Pemerintah Nomor 66 Tahun 2010 tentang Perubahan Atas Peraturan Pemerintah Nomor 17 Tahun 2010, merupakan bentuk satuan pendidikan formal yang menyelenggarakan pendidikan kejuruan pada jenjang pendidikan menengah sebagai lanjutan dari SMP, MTs, atau bentuk lain yang sederajat atau lanjutan dari hasil belajar yang diakui sama atau setara SMP/MTs. Tujuan utamanya untuk mempersiapkan lulusan yang siap memasuki dunia industri kerja. Untuk itu pengelolaan atau manajemen dari berbagai program ataupun kegiatan di SMK harus dilaksanakan secara efektif dalam upaya mencapai tujuan tersebut (Sugiyono, 2016).

Mulyono (2010) menyatakan manajemen adalah melaksanakan suatu kegiatan melalui orang lain. Dalam upaya pencapaian tujuan SMK, peran serta masyarakat sangat diharapkan dalam mendukung dan berpartisipasi untuk meningkatkan kualitas pendidikan di sekolah. Masyarakat dimaksud adalah Dunia Usaha dan Dunia Industri (Dudi); hal tersebut akan dapat secara optimal terlaksana melalui peran yang optimal pula dari bagian Hubungan Masyarakat (Humas) yang ada di sekolah (Irawanda \& Bachtiar, 2020). Abdurrahman (dalam Suryosubroto, 2012) menyatakan Humas adalah kegiatan untuk menanamkan dan memperoleh pengertian, dukungan, kepercayaan, serta penghargaan pada dan dari publik suatu badan pada khususnya dan masyarakat pada umumnya. Humas adalah keseluruhan kegiatan yang dijalankan suatu organisasi terhadap pihak lain dalam rangka pembinaan pengertian dan memperoleh dukungan pihak lain itu demi tercapainya tujuan organisasi dengan sebaik-baiknya (Minarti, 2016). Humas berfungsi untuk membina hubungan secara harmonis antara organisasi dan publik, baik internal maupun eksternal (Kusumastuti, 2002). Melalui optimalisasi peran Humas akan menjadikan kerjasama sekolah dengan masyarakat (Dudi) sebagai kebutuhan dasar demi kelancaran pendidikan di sekolah pada umumnya dan untuk meningkatkan prestasi belajar siswa serta lulusan terutama dalam era revolusi industri 4.0 agar sesuai dengan perkembangan yang terjadi di Dudi saat ini atau tidak ada "gap" antara kompetensi yang dipersiapkan di sekolah dengan kebutuhan nyata pekerjaan pada Dudi; sehingga dalam upaya tersebut SMK harus menyelaraskan progam pendidikannya. Hal tersebut tertuang dalam Peraturan Menteri Perindustrian (Permenperin) Nomor 3 Tahun 2017 tentang Pedoman Pembinaan dan Pengembangan Sekolah Menengah Kejuruan Berbasis Kompetensi yang menuntut adanya link and match antara sekolah dengan Dudi. Dalam upaya tersebut Dudi juga diharapkan untuk dapat memfasilitasi pembinaan kepada SMK terutama bagi peserta didik untuk mendapatkan kesempatan dan pengalaman kerja untuk menguasai kompetensi keahlian professional, dalam menghasilkan tenaga kerja yang terampil dan sesuai kualifikasi.

Salah satu sekolah di Kota Palangka Raya yang efektif melaksanakan kerjasama sekolah dengan Dudi melalui peran Humas adalah SMKN 3 Palangka Raya. Peran Waka. Humas dalam membangun/menjalin kerjasama yang harmonis dan berkesinambungan dengan Dudi berkontribusi dalam meningkatkan kualitas lulusan, salah satunya pada jurusan Perhotelan yang menjalin kerjasama Prakerin dengan dunia industri hotel dalam bentuk perjanjian kerjasamanya (MoU) dengan hotel berbintang 3 keatas di Kota Palangka Raya, seperti: Aquarius Boutique Hotel, Luansa Hotel, Swissbel Hotel Danum, dan Neo Hotel. Peran Humas sebagai ujung tombak untuk merealisasikan program Prakerin menjadi suatu keniscayaan. Noer (2014) menyatakan Prakerin merupakan suatu proses pendidikan keahlian profesional yang memadukan secara sistematik antara program pendidikan di sekolah dengan program penguasaan keahlian yang diperoleh melalui kegiatan bekerja secara langsung pada dunia kerja, dan terarah untuk mencapai suatu tingkat keahlian profesional tertentu. SMKN 3 Palangka Raya melalui peran Humas dalam mengelola program Prakerin jurusan Perhotelan menyukseskan visi dan misi sekolah. Humas menjadi ujung tombak dalam mewujudkan link and match agar sesuai dengan kebutuhan Dudi bertujuan untuk meningkatkan keterserapan dan kualitas lulusan yang terampil sesuai kebutuhan industri terutama di perhotelan, dan mampu bersaing dalam dunia kerja untuk menghadapi zaman yang semakin berkembang era revolusi industri 4.0 saat ini dengan baik. 
Secara umum penelitian ini bertujuan untuk mendeskripsikan tentang Manajemen Hubungan Masyarakat (Humas) dalam Program Praktik Kerja Industri Jurusan Perhotelan di SMKN 3 Palangka Raya, dilihat dari aspek: (1) perencanaan Humas, (2) pengorganisasian Humas, (3) pelaksanaan Humas, (4) pengawasan Humas, dan (5) evaluasi Humas.

\section{METODE}

Penelitian ini merupakan penelitian kualitatif dengan rancangan studi kasus. Bagdon \& Taylor (dalam Moleong, 2012) menyatakan penelitian kualitatif adalah prosedur penelitian yang menghasilkan data deskriptif berupa kata-kata tertulis atau lisan dari orang-orang dan perilaku yang dapat diamati. Sumber data penelitian ini adalah Kepala Sekolah, Wakil Kepala Sekolah bidang Humas dan Ketua Program Keahlian bidang Perhotelan di SMKN 3 Palangka Raya. Pengumpulan data dilakukan dengan menggunakan metode observasi, wawancara dan dokumentasi. Analisis data dilakukan melalui tahapan: (1) Pengumpulan Data, (2) Reduksi Data, (3) Penyajian Data, dan (4) Penarikan Kesimpulan, untuk mencari dan menyusun secara sistematis data yang diperoleh dari hasil wawancara, catatan lapangan, dan dokumentasi dengan cara mengorganisasikan data ke kategori, menjabarkan ke dalam unit-unit, melakukan sintesa, menyusun kedalam pola, memilih yang penting dan akan dipeajari, dan membuat kesimpulan sehingga mudah dipahami oleh diri sendiri dan orang lain (Sugiyono, 2014). Pengabsahan Data dalam penelitian ini menggunakan teknik triangulasi sebagaimana dijelaskan Moleong (2012) bahwa untuk menetapkan keabsahan data diperlukan teknik pemeriksaan, salah satunya adalah melalui triangulasi sebagai teknik pemeriksaan keabsahan data yang memanfaatkan sesuatu yang lain. Dalam penelitian ini teknik triangulasi digunakan untuk membandingkan data hasil observasi, wawancara serta dokumentasi.

\section{HASIL DAN PEMBAHASAN \\ Perencanaan Humas dalam Program Prakerin}

Berdasarkan hasil temuan penelitian diketahui bahwa perencanaan dalam manajemen Humas pada program Prakerin pada jurusan Perhotelan di SMKN 3 Palangka Raya dilakukan dengan menetapkan tujuan, yaitu membangun hubungan yang sinergis dengan pihak Dudi. Dalam upaya tersebut pihak Humas menyiapkan perjanjian kerjasama (MoU) dengan hotel-hotel bintang 3 keatas di Kota Palangka Raya, seperti: Aquarius Boutique Hotel, Luansa Hotel, Swissbel Hotel Danum, dan Neo Hotel. Melalui MoU tersebut juga ditujukan untuk melaksanakan berbagai kegiatan seperti: melibatkan Dudi perhotelan sebagai tempat pelaksanaan Prakerin, melibatkan Dudi dalam penyelarasan kurikulum, guru magang, guru tamu, perekrutan tamatan (lulusan), serta menyiapkan lulusan SMK agar memiliki keahlian sebagai tenaga kerja yang kompeten dan terampil sesuai dengan kebutuhan dunia kerja. Proses perencanaan oleh bagian Humas ini melibatkan berbagai pihak baik internal maupun eksternal, seperti: Kepala Sekolah, Dinas Pendidikan sebagai Pembina SMK, Waka. Kurikulum, Waka. Humas dan Staf Humas, Ketua Program Keahlian Perhotelan, dan Guru Produktif serta pihak manajemen hotel. Temuan penelitian ini sejalan dengan pendapat Wena (1997) bahwa langkah yang harus dilakukan sekolah dalam menjalin kerjasama dengan Dudi yaitu memilih industri pasangan, pihak sekolah mendatangi Dudi yang bersangkutan, membuat surat perjanjian kerjasama kedua belah pihak, setelah disepakati mulailah membuat kegiatan nyata terkait prakerin. Dalam upaya tersebut, Daryanto (2001) menyatakan peran dan tujuan Humas adalah untuk mencegah kesalahpahaman (to prevent misunderstanding), mendapatkan hubungan dan bantuan moral maupun finansial yang dibutuhkan bagi pengembangan sekolah (to secure financial support), menjalin kerjasama dalam pembuatan kebijakan baru (to secure copparation in policy making). Pengikutsertaan dari berbagai stakeholder akan menimbulkan perasaan ikut memiliki yang dapat memberikan dorongan kepada guru dan personil sekolah yang lain untuk berusaha agar rencana tersebut berhasil (Moedjiarto dalam Sagala, 2009). Lebih lanjut Nasution (2010) menjelaskan bahwa fungsi pokok dalam perencanaan program oleh Humas dilakukan untuk menetapkan apa yang ingin dicapai, bagaimana mencapai, berapa lama, berapa orang yang diperlukan, dan berapa jumlah biaya yang dibutuhkan untuk merealisasikan program tersebut. 


\section{Pengorganisasian Humas dalam Program Prakerin}

Berdasarkan hasil temuan penelitian diketahui bahwa pengorganisasian dalam manajemen Humas pada program Prakerin pada jurusan Perhotelan di SMKN 3 Palangka Raya dilakukan dengan melaksanakan rapat koordinasi internal sekolah dan pembuatan Surat Keputusan (SK) pelaksanaan Program Prakerin jurusan Perhotelan dari Kepala Sekolah selaku penanggung jawab. Dalam SK tersebut menugaskan Waka. Humas sebagai Ketua Koordinator dan dibantu staf Humas, untuk melakukan koordinasi langsung dengan Ketua Program Keahlian Perhotelan dan Guru Produktif sebagai pembimbing yang sudah mengetahui peran tugas dan tanggung jawabnya masingmasing sehingga program dapat berjalan sesuai yang sudah direncanakan. Temuan penelitian ini sejalan dengan pendapat Purwanto (1991) bahwa pengorganisasian merupakan aktivitas menyusun dan membentuk hubungan-hubungan kerja sama orang-orang sehingga terwujud suatu kesatuan usaha dalam mencapai tujuan-tujuan yang telah ditetapkan. Penetapan personil serta tugas dan tanggung jawab dalam pelaksanaan Program Prakerin tersebut dilakukan dengan tujuan untuk efektivitas pencapaian tujuan Prakerin sebagai salah satu tujuan sekolah. Proses penentuan dan pengelompokkan pekerjaan yang akan dikerjakan, menetapkan dan melimpahkan wewenang dan tanggung jawab ditujukan untuk memungkinkan orang-orang bekerja sama secara efektif dalam mencapai tujuan (Hasibuan, 2014).

\section{Pelaksanaan Humas dalam Program Prakerin}

Berdasarkan hasil temuan penelitian diketahui bahwa proses pelaksanaan dalam manajemen Humas pada program Prakerin dilakukan dengan mempersiapkan kelengkapan administrasi, berupa surat pengantaran siswa prakerin dan surat tugas guru pembimbing. Setelah persiapan administrasi selesai selanjutnya mempersiapkan dokumen yang dibutuhkan, meliputi: presensi siswa, jurnal, blanko penilaian, format atau laporan magang siswa. Setelah semua kelengkapan administrasi selesai, selanjutnya melakukan koordinasi dengan Ketua Jurusan dan Guru pembimbing untuk melaksanakan pengantaran siswa magang ke tempat pelaksanaan magang (hotel). Dalam pelaksanaan pengantaran siswa tersebut, pihak sekolah menyerahkan kelengkapan administrasi kepada pihak manajemen hotel serta secara simbolik menyerahkan siswa untuk mendapatkan pembinaan dan bimbingan sesuai dengan mekanisme kerja yang ada pada hotel. Selanjutnya Waka. Humas bersama guru pembimbing melakukan koordinasi dengan manajemen hotel terkait sinergisitas pelaksanaan magang agar dalam pelaksanaannya dapat berjalan dengan efektif. Setelah pelaksanaan magang selesai, selanjutnya Waka. Humas melakukan koordinasi dengan Ketua Program Keahlian Perhotelan dan guru pembimbing untuk membimbing siswa dalam penyusun laporan diakhir kegiatan magang. Temuan penelitian ini sejalan dengan pendapat Terry (1993) bahwa penggerakan atau pelaksanaan merupakan aktualisasi dari perencanaan dan pengorganisasian secara kongkrit. Perencanaan dan pengorganisasian tidak akan mencapai tujuan yang ditetapkan tanpa adanya aktualisasi dalam bentuk pelaksanaan kegiatan. Singkatnya actuating mencakup kegiatan yang dilakukan seorang yang ditetapkan manager untuk mengawali dan melanjutkan kegiatan yang telah ditetapkan oleh unsur perencanaan dan pengorganisasian agar tujuan-tujuan dapat tercapai. Siagian (2007) menyatakan penggerakan atau pelaksanaan merupakan keseluruhan usaha, cara, teknik, dan metode untuk mendorong para anggota organisasi agar mau dan ikhlas bekerja dengan sebaik mungkin demi tercapainya tujuan organisasi dengan efisien, efektif, dan ekonomis.

\section{Pengawasan Humas dalam Program Prakerin}

Berdasarkan hasil temuan penelitian diketahui bahwa pengawasan atau monitoring dalam manajemen Humas pada program Prakerin dilakukan dengan melaksanakan monitoring yang terjadwal sesuai kesepakatan dengan pihak hotel. Monitoring dilakukan oleh Ketua Program Keahlian dan Guru pembimbing. Monitoring ini dilaksanakan untuk mengetahui efektivitas pelaksanaan selama Prakerin berlangsung, yang biasanya dilakukan minimal 1 bulan sekali. Jika 
dalam pelaksanaan monitoring ditemukan masalah atau kendala, maka pihak-pihak tersebut melaporkan kepada Waka. Humas untuk menindaklanjuti hasil temuan monitoring tersebut. Waka. Humas selalu mengingatkan dan memberikan arahan kepada guru pembimbing agar senantiasa berkoordinasi dengan pihak manajemen hotel agar kegiatan Prakerin dapat berjalan dengan baik dan efektif sesuai yang telah direncanakan. Hasil temuan penelitian ini sejalan dengan pendapat Siagian (2003) pengawasan adalah proses pengamatan dari pelaksanaan seluruh kegiatan organisasi untuk menjamin agar semua pekerjaan yang sedang dilakukan berjalan sesuai dengan rencana yang telah ditentukan sebelumnya. Pengawasan merupakan kegiatan yang dilakukan untuk menjamin kegiatankegiatan atau program-program telah berjalan sesuai dengan perencanaan untuk mencapai tujuan. Pengawasan sangat erat kaitannya dengan perencanaan, karena melalui pengawasan efektivitas manajemen dapat diukur (Barnawi \& Arifin, 2014).

\section{Evaluasi Humas dalam Program Prakerin}

Berdasarkan hasil temuan penelitian diketahui bahwa evaluasi dalam manajemen Humas pada program Prakerin dilakukan dengan mengevaluasi atau melakukan penilaian terhadap laporan pelaksanaan kegiatan Prakerin secara keseluruhan, yang diperoleh dari: laporan monitoring, laporan magang siswa, hasil persensi siswa, hasil blanko penilaian yang telah dilakukan oleh pihak hotel serta feedback dari pihak hotel. Berdasarkan laporan yang masuk kepada pihak Humas tersebut, selanjutnya pihak Humas membuat laporan akhir pelaksanaan Prakerin yang ditujukan kepada Kepala Sekolah untuk ditembuskan kepada Dinas Pendidikan Provinsi Kalimantan Tengah. Hasil evaluasi kegiatan Prakerin ini disampaikan dalam rapat sekolah bersamaan dengan laporan kegiatan sekolah lainnya diakhir tahun, untuk mereview efektivitas pelaksanaan program sekolah termasuk program Prakerin sehingga menjadi acuan untuk memperbaiki dan meningkatkan kualitas pelaksanaan program kerja Humas di masa mendatang. Hasil temuan penelitian ini sejalan dengan pendapat Effendy (2002) bahwa evaluasi atau penilaian berfungsi untuk mengkaji pelaksanaan suatu rencana yang terdiri atas program-program yang dalam penyusunannya ditunjang oleh hasil penelitian yang dilakukan secara seksama dan dalam evaluasi dilakukan telaah terhadap faktorfaktor penghambat dalam perencanaan atau dalam proses pelaksanaannya. Pada konteks evaluasi dalam pelaksanaan program Humas pada lembaga pendidikan dilaksanakan untuk: (1) memperoleh informasi yang diperlukan untuk meningkatkan produktifitas serta keefektifan belajar siswa dan pengembangan sekolah, (2) memperoleh feedback, (3) memperoleh informasi yang diperlukan untuk memperbaiki dan menyempurnakan proses pembelajaran di sekolah, (4) memperoleh informasi yang diperlukan untuk memperbaiki, menyempurnakan serta mengembangkan program, dan (5) mengetahui kesukaran-kesukaran apa yang dialami siswa selama belajar dan bagaimana mencari jalan keluarnya (Slameto, 1988).

\section{SIMPULAN}

Berdasarkan hasil dan pembahasan penelitian dapat disimpulkan bahwa secara umum pelaksanaan program Prakerin yang dikelola oleh bagian Humas SMKN 3 Palangka Raya berjalan dengan baik dan efektif dalam meningkatkan kompetensi siswa dan lulusan yang sesuai kebutuhan Dudi bidang perhotelan. Perencanaan program Prakerin dilakukan dengan menetapkan tujuan, menyiapkan perjanjian kerjasama (MoU), melibatkan Dudi perhotelan sebagai tempat pelaksanaan Prakerin, melibatkan Dudi dalam penyelarasan kurikulum, guru magang, guru tamu, perekrutan tamatan (lulusan), serta menyiapkan lulusan SMK agar memiliki keahlian sebagai tenaga kerja yang kompeten dan terampil sesuai dengan kebutuhan dunia kerja. Pengorganisasian dilakukan dengan melakukan rapat koordinasi internal sekolah dan pembuatan Surat Keputusan (SK) pelaksanaan Program Prakerin. Pelaksanaan dilakukan dengan mempersiapkan kelengkapan administrasi, serta mekanisme pelaksanaan program Prakerin oleh semua pihak yang terlibat. Pengawasan atau monitoring dilakukan terjadwal untuk mengetahui efektivitas pelaksanaan selama Prakerin berlangsung. Evaluasi dilakukan dengan mengevaluasi atau melakukan penilaian terhadap laporan pelaksanaan kegiatan Prakerin secara keseluruhan, yang diperoleh dari: laporan monitoring, laporan 
magang siswa, hasil persensi siswa, hasil blanko penilaian yang telah dilakukan oleh pihak hotel serta feedback dari pihak hotel.

\section{UCAPAN TERIMAKASIH}

Ucapan terima kasih penulis sampaikan kepada pihak sekolah SMKN 3 Palangka Raya yang telah memberikan izin kesempatan dan kemudahan serta dukungan penuh bagi penulis selama berlangsungnya proses kegiatan penelitian, serta tim redaksi Equity in Education Journal (EEJ) Program Studi Manajemen Pendidikan FKIP Universitas Palangka Raya yang telah memberikan kesempatan artikel kami ini dapat dipublikasikan dalam jurnal ini.

\section{DAFTAR PUSTAKA}

Barnawi., \& Arifin, M. (2014). Manajemen Sarana dan Prasarana Sekolah. Yogyakarta: Ar-Ruzz Media.

Daryanto. (2001). Administrasi Pendidikan. Jakarta: Rineka Cipta.

Effendy, O. U. (2002). Hubungan Masyarakat Suatu Studi Komunikologis. Bandung: PT Remaja Rosdakarya.

Hasibuan, M. S. P. (2014). Organisasi dan Motivasi: Dasar Peningkatan Produktivitas. Jakarta: Bumi Aksara.

Irawanda, G., \& Bachtiar. (2020). Manajemen Hubungan Sekolah dan Masyarakat di SMK Negeri Makassar. Jurnal Administrasi, Kebijakan, dan Kepemimpinan Pendidikan, 1(1).

Kusumatuti, F. (2002). Dasar-Dasar Hubungan Masyarakat. Jakarta Selatan: Ghalia Indonesia.

Minarti, S. (2016). Manajemen Sekolah: Mengelola Lembaga Pendidikan Secara Mandiri. Yogyakarta: Ar-Ruzz Media.

Moleong. L. J. (2012). Metode Penelitian Kualitatif. Bandung: PT. Remaja Rosdakarya.

Mulyono. (2010). Manajemen Administrasi dan Organisasi. Solo: Ar-Ruzz.

Nasution, Z. (2010). Manajemen Humas di Lembaga Pendidikan (Konsep, Fenomena dan Aplikasinya). Malang: UMM Press.

Noer, F. (2014, 13-14 November). Pemantapan Keterampilan Siswa SMK Negeri 3 Banda Aceh Melalui Kegiatan Prakerin. Makalah disajikan pada Konvensi Nasional APTEKINDO VII, FPTK Universitas Pendidikan Indonesia, Bandung. Diterima dari http://repository.unesa.ac.id/sysop/files/2021-06-22_Prosiding:\%20Pengembangan\% 20Modul_puput\%20wanarti.pdf.

Peraturan Menteri Perindustrian (Permenperin) Nomor 3 Tahun 2017 tentang Pedoman Pembinaan dan Pengembangan Sekolah Menengah Kejuruan Berbasis Kompetensi.

Peraturan Pemerintah (PP) Nomor 66 Tahun 2010 tentang Perubahan Atas Peraturan Pemerintah Nomor 17 Tahun 2010 tentang Pengelolaan dan Penyelenggaraan Pendidikan.

Purwanto, M. N. (1991). Administrasi dan Supervisi Pendidikan. Bandung: PT Remaja Rosdakarya. Sagala, S. (2009). Konsep dan Makna Pembelajaran. Bandung: CV. Alfabeta.

Siagian, S. P. (2003). Teori \& Praktek Kepemimpinan. Jakarta: Rineka Cipta.

Siagian, S. P. (2007). Fungsi-Fungsi Manajerial. Jakarta. Bumi Aksara.

Slameto. (1988). Evaluasi Pendidikan. Jakarta: PT. Bina Aksara.

Sugiyono. (2014). Metodologi Penelitian Manajemen. Bandung: Alfabeta.

Sugiyono. (2016). Manajemen Pendidikan Kejuruan. Yogayakarta: Fakultas Teknik. Diterima dari http://eksis.ditpsmk.net/uploads/book/file/0773E9DA-AD01-4A95-B744-10C573BD1550/ Manajemen_Pendidikan_2016_.pdf.

Suryosubroto. (2012). Hubungan Sekolah dengan Masyarakat (School Public Relation). Jakarta: Rineka Cipta.

Terry, G. R. (1993). Prinsip-Prinsip Manajemen. Jakarta: Bumi Aksara.

Undang-Undang Nomor 20 Tahun 2003 tentang Sistem Pendidikan Nasional.

Wena, M. (1997). Pemanfaatan Industri sebagai Sumber Belajar. Jurnal Pendidikan dan Kebudayaan, 3(10). 